\title{
Research on the Linguistic Features of English Advertisements
}

\author{
Lizhu $\mathrm{Ni}$ \\ Haikou College of Economics, Haikou, Hainan, 571127, China
}

\begin{abstract}
Now, the media industry has been vigorously developed in the basic universal access of the computer. Advertising is a form of information dissemination of goods. In order to present the exact product information to the public in a short time, ad copy planning is critical. In ad copy planning, advertising language composition is particularly important. Today English advertising is abound, the analysis of the language characteristics of English advertising is the foundation of planning a good English advertising copy. This paper explores the linguistic features of English advertisements from the aspects of vocabulary, grammar and rhetoric.
\end{abstract}

Keywords: English; advertising; language features

\section{Introduction}

In the context of economic globalization, the Chinese market, there has been an increasing number of foreign products. From the publicity point of view, advertising both to disseminate information, develop new markets, but also to guide consumption, expand sales, is the most effective media publicity. However, because of the language habits and cultural backgrounds of our country, there are obvious differences between our country and our country. Therefore, the advertising language has a very significant linguistic feature. 


\section{The basic characteristics of English advertising}

Advertising is a product of the process of commercial competition. It is the nearest distance between businesses and consumers to connect the information bridge. As a means of communication with certain promotional capabilities, advertising needs to be gradually implemented "A - I - D - A". More specifically, the term "attracting attention" ("attracting interest to the recipient of the message") - "Desire" - "the action of buying")" [1]. Based on this, we can see that advertising planning is a certain degree of skill. The advertising rhetoric related to the national, cultural, consumer spending habits, the consumer psychology (Figure 1), advertising, advertising, advertising, and so on, Appreciation and aesthetic taste and many other factors; features two, embodies a profound cultural connotations [2].

\section{The language features analysis of English advertising}

\subsection{Lexical characteristics of English advertising}

The characteristics of English advertisements are very obvious. First of all, English monosyllabic verbs (simple and clear words) are used in English advertisements. Domestic people's English is limited, simple monosyllabic verbs are more likely to accept the audience, combined with its concise, easy to remember, catchy, better achieve the purpose of promoting consumer purchase [3]. In English advertisements, smile, feel, go, stay, come, love and so is the use of high frequency words, these words dynamic strong, consumers remember easier. For example, (1) Obey your thirst. Obey your desire - (Sprite), the verb "Obey". (2) Take time to indulge. Have fun! (Nestle ice cream), the verb "Take". (3) Come to where the flavor is Marlboro Country. Visit the world of charm Marlboro world, (Marlboro cigarettes), the verb "Come". (4) Ask for more. Crave unlimited (Pepsi popular shoes), the verb "Ask". (5) Start Ahead. (Rejoice, the road to success, from scratch (Rejoice). Second, the use of English ad evaluation adjectives is more. In order to show consumers the characteristics of goods, English ads will be new, good, young, great and so on to join. Dripping fragrant, something more to say. (Maxwell Coffee). (2) The new digital era. (3) The taste is great. (Nestle Coffee). In addition, there are some ads that combine monosyllabic verbs with evaluative adjectives, such as Feel the new space. (Samsung Electronics). Finally, the frequency of colloquial words in English advertisements is also very high. In English advertisements, colloquial expressions are expressed mainly through the extensive use of acronyms. Colloquialism is both appealing and more relevant to the general public. For example, "Tide's in, dirt's out" (Tide in, dirt washed out). In short, the vocabulary characteristics of English advertising can be summarized as the use of monosyllabic verbs, evaluative adjectives and colloquial words more. In addition, some English advertising vocabulary is some new words. New words more attractive and better reflect the special point of their products or services. For 
example, "Kleenex" - "Kleenex", "Superfine" - "Super fly". TWOGETHER - The ultimate all inclusive one price sun kissed holiday.

\subsection{Syntactic features of English advertisements}

In English advertisements, the syntactic features can be summarized as follows: First, the common phrases replace the whole sentence. Advertising in a limited time, in a few seconds, in order to allow advertising in the shortest possible time to maximize the effectiveness of the need in this only a few seconds straight grab the needs of consumers and show the characteristics of their products, need to choose the appropriate sentence [4]. For example, (1) Take Toshiba, take the world. Owns Toshiba, owns the world - Toshiba Electronics. (2) intelligence everywhere, wisdom omnipresent-Motorola phones. Second, often use imperative sentence. Imperative sentence tone is more intense, more in line with the characteristics of advertising. For example, in the seven-up ads, mentioned "Fresh-up with Seven-up. And "Make yourself heard. (Ericsson), understanding is communication - Ericsson." The ads, both simple and clear to the publicity of information, but also show the characteristics. "Nike sports shoes" ads - Just do it. Just do it. First-person, second-person use more easily narrowed the distance with the consumer, so that consumers have a sense of closeness. This easy, natural way of communicating with consumers is more conducive to consumer acceptance of the product. Let us make it better - Philips, which uses the "us", will itself and the consumer to form a natural front, standing in the consumer's point of view to encourage Consumers do better. (2) You make it happen (only to do, is it possible) - Lancome.

\subsection{The rhetorical features of English advertising}

English advertisements pay more attention to the use of rhetorical devices based on the accuracy of vocabularies and the rationality of syntax. Advertising rhetoric can be said to be the crowning touch of advertising. Advertising English only use good rhetoric, in order to gain popular advertising effect. Should the use of rhetoric improper, advertising will appear dull. English advertising can be used more types of rhetoric, roughly including pun, exaggeration, rhyme, metaphor, anthropomorphic, repetition, ranking, etc. The following will be a detailed analysis:

First, the use of "puns" rhetoric (it means the conscious use of homonyms or the word polysemy to form a sentence to express two different meanings). For example, (1) Intel Inside. (Intel Pentium) to the computer a Pentium "core."Which uses the "heart - core", expressed a different meaning of the two. (2) Feet your eyes. (Pond's Cucumber Eye Treatment) Paint your eyes.

Second, the use of exaggerated highlights product features. "Exaggeration" is a conventional way of rendering the product, the use of more. For example, ake toshiba, take the world. Owns Toshiba, owns the world - Toshiba Electronics. (Crest toothpaste)

Third, English advertising, the use of rhyming rhetoric hand is not uncommon. The use of rhyming rhetoric can make the ad rich rhythm, the audience is easier 
to remember. Usually, the use of rhyming rhetoric is divided into two kinds, one is the charge "alliteration." For example, Good teeth, good health, good health Colgate toothpaste. Here, "good" is used twice, and "teeth" and "health" are similar. The other is to use the "rhyme" (in a sentence using more than two at the end of the same word)

This sounds more profound, and easy to pass on. For example, (1) the taste is great. Nestle coffee. (2) Oimpossible made possible. Making the impossible possible - Canon printer. (3) We integrate, you communicate. We integrate and you go beyond self - Mitsubishi Electric. (4) Clear it up, do not cover it up. Clear it, do not cover it up. 5) Cooking without looking - do not need to see rice cooked rice cooked rice). (6) My godness, my Guinness - Guinness Stout.

Fourth, the use of metaphor rhetoric, in English advertising, simile, metaphor, metonymy more frequently used. Especially in the ad title, metaphor rhetoric is more prominent. The use of metaphor in ad writing rhetoric, one can make the image more vivid, showing the goods, services and even ideas; two will be goods, services and even ideas to do something like something that can attract the audience to promote their actions. For example, "The stomach, how are you?" Stacey stomach medicine.

In addition, the use of rhetoric there are many, such as anthropomorphic, repetition, parallelism, etc., these rhetorical devices have one thing in common is to show consumers the concept and characteristics of the product. It is worth mentioning that the use of a lot of imitation. The so-called "imitation", that borrows a famous poem, articles, paragraphs or a famous, aphorisms, proverbs, style and other organizations advertising. The road to success, from scratch Rejoice shampoo, in the slogan, the use of famous aphorisms.

\section{Conclusion}

English advertising has been very common in today's society and the purpose of English advertising is to promote the product, so that consumers see the desire to buy products after advertising. A good English advertising will be remembered in mind and plays a very good publicity. The linguistic features of English advertisements are mainly embodied in vocabulary, syntax and rhetoric, and the use of foreign exchange, syntax and rhetoric can be used to obtain unexpected advertisements. Grasping the distinctive features of rhetoric, vocabulary, and syntax in English advertising language is beneficial to maximizing the publicity of its products, services or ideas, increasing its popularity and quickly occupying a broader market.

\section{Acknowledgements}

Hainan Province Education and Teaching Reform Research Project: Research and Practice of Improving English Autonomous Learning Ability of College Students under Multimodal Teaching Environment - Based on Exploring the Use of Library Network Resources(Hnjg2015-64). 


\section{References}

[1] Zhoumeng, Yu Shoucai. On the Language Features and Translation Skills of English Advertisement. Journal of Changsha Railway Institute (Social Science Edition), 55(12), pp.68-70, 2012

[2] Chenghu. An Analysis of Stylistic Features of English Advertising Language - A Case Study of Newsweek. Journal of Hubei Correspondence University, 8 (5), pp.87- 91, 2011

[3] Bai Bing. Linguistic Features of Advertising English. Journal of Liaoning Economic Management Cadre Institute (Liaoning Economic Vocational Technological Institute), 12(10), pp. 18- 20, 2014

[4] Ni Xiujing. Linguistic Features, Rhetorical Features and Translation Methods of English Advertisements. College English (Academic Edition), 9(6), pp.58- 61, 2015

[5] Zhang Li. Discussion on the English Translation Skills of Chinese Advertisement from the Language Features of English Advertisement, 8(4), pp.85-87, 2014 